\title{
SYMPTOMS VARIATION OF VIRAL INFECTIONS IN YARDLONG BEAN
}

\author{
Supyani, Dwiwiyati Nurul Septariani, \& Hadiwiyono \\ Study Program of Agrotechnology, Faculty of Agriculture, Sebelas Maret University, Indonesia \\ Jl. Ir. Sutami No. 36A, Jebres, Kecamatan Jebres, Kota Surakarta, Jawa Tengah 57126 \\ E-mail: supyani.id@gmail.com
}

Manuscript received: 22 October 2019. Revision accepted: 1 March 2020

\begin{abstract}
Symptoms variation of viral infections in yardlong bean. Yardlong bean (Vigna unguiculata subsp. sesquipedalis L.) is an important horticultural commodity in Indonesia. During the last ten years, yardlong bean planting areas in Indonesia especially in Java often suffered from epidemics of viral disease showing typical symptoms of yellow mosaic on their leaves. Some researchers have separately reported that the symptoms associated with some viral infections. This research aimed to examine viruses associated with the symptoms of yellow mosaic on yardlong bean in endemic areas in Sukoharjo, Central Java, Indonesia. Yardlong bean leaves were taken from the district by purposive sampling method, then the virus was detected by nucleic acid amplification using specific primers for Begomovirus, Bean common mosaic virus (BCMV) and Cucumber mosaic virus (CMV). The results showed that one sample of yardlong bean could be infected by more than one virus. Infection of two kind of virus in a yardlong bean showed symptoms of each virus plus a synergistic effect where the symptoms become more severe.
\end{abstract}

Key words: BCMV, CMV, detection, Geminivirus, Potyvirus

\section{INTRODUCTION}

Yardlong bean (Vigna unguiculata subsp. sesquipedalis L.) is an important horticultural commodity in Indonesia. Besides being easily cultivated in various land conditions, this plant is also a cheap source of protein. It also has ability to fertilizes the soil because it belongs to the Leguminosae family (Duriat, 1998; Sastro, 2016). Till date, the production of yardlong bean in Indonesia has not been maximized, one of the causal is a viral infection (Taufik, 2015).

Various viruses were reported to infect yardlong bean. The presence of yellow mosaic disease in yardlong bean in Java was first reported in 2008 (Damayanti et al., 2009). This disease was associated with infection of Begomovirus, Bean common mosaic virus (BCMV) and Cucumber mosaic virus (CMV) (Damayanti et al., 2009; Tsai et al., 2013). In Indonesia, other viruses that were found to infect yardlong bean are Bean yellow mosaic virus (BYMV), Cowpea chlorotic mottle virus (CCMV), Cowpea golden mosaic virus (CGMV), Cowpea aphid-borne mosaic virus (CabMV), and Southern bean mosaic virus (SBMV) (Semangun, 2004; Triharso et al., 1998). These viruses can infect singly (individually) or double/multiple infections (infection with more than one type of virus).
Procedurally, the diagnosis of viral disease in plants begins with observation of symptoms. Some viral diseases in plants have been easily diagnosed based only on observations of the symptoms. Double or multiple infections besides worsen the disease, they also obscure the symptom of each infecting virus and make it difficult to diagnose.

This research aimed to detect the presence of viruses in some sample of yardlong bean leaves showing a certain symptoms. Detection was carried out by viral genome amplification method. The relationship between viruses infecting yardlong bean and their symptoms are described in this study. Some detected viruses in this study were also analyzed for their nucleic acids genomes, therefore the relationship to their closely related viruses were revealed.

\section{MATERIALS AND METHODS}

Research Site. The research was conducted in yardlong bean centers in Sukoharjo Regency, Central Java Province, Indonesia. Samples of yardlong bean leaves were collected from endemic areas of viral diseases in the district. 
Collection of Yardlong Bean Samples. Yardlong bean leaves showing symptoms of viral disease in vegetative phase were selected by purposive sampling method. Fresh leaves samples were detected for the presence of virus/(s) and the rest were stored as virus isolates collection in the laboratory at $-20^{\circ} \mathrm{C}$.

Extraction of Total RNA. Total RNA was isolated from infected leaf following a procedure described by Doyle \& Doyle (1987) with minor modification. Fresh tissue $(0.1 \mathrm{~g})$ was ground in liquid Nitrogen to powder followed by addition of $500 \mu \mathrm{L}$ of CTAB buffer $(10 \%$ Cetyl-trimethyl-ammonium bromide, $0.1 \mathrm{M}$ Tris- $\mathrm{HCl}$ pH 8.0, 0.05 M EDTA, $0.5 \mathrm{M} \mathrm{NaCl}, 1 \%$ ß-mercaptoethanol). Lipid and protein then separated by incubation in a water bath at $65^{\circ} \mathrm{C}$ for $30 \mathrm{~min}$, followed by shaking every $10 \mathrm{~min}$. The debris was pelleted by addition of $500 \mu \mathrm{L}$ of chloroform/isoamyl alcohol $(24: 1, \mathrm{v} / \mathrm{v})$, vortexed for $5 \mathrm{~min}$ and centrifuged at 10,000 rpm for $15 \mathrm{~min}$. RNA was precipitated by addition of $3 \mathrm{M}$ ammonium acetate and isopropanol then incubated for $30 \mathrm{~min}$ at $-80^{\circ} \mathrm{C}$, followed by centrifugation at $10,000 \mathrm{rpm}$ for 7 min. RNA pellet was dissolved in $50 \mu \mathrm{L}$ of TE buffer $1 \mathrm{x}$ (10 mM Tris-HCl pH 8.0, 1 mM EDTA) and was ready for Reverse Transcription-Polymerase Chain Reaction (RT-PCR).

Potyvirus Detection by RT-PCR. Total RNA was used as template for one-step Reverse TranscriptionPolymerase Chain Reaction (RT-PCR). One-step RTPCR reaction contains $2 \mu \mathrm{L}$ RNA total, $12.5 \mu \mathrm{L}$ premix Go Taq Green (Promega Japan), $1 \mu \mathrm{L}$ each of primer MJ1 (5'-ATGGTHTGGTGYATHGARAAYGG-3') and MJ2 (5'-TGCTGCKGCYTTCATYTG-3') (MarieJeanne et al., 2000), $2 \mu \mathrm{L}$ DTT (dithiothreitol) $50 \mathrm{mM}$, $0.1 \mu \mathrm{L}$ M-MuLV $(200 \mathrm{U} / \mu \mathrm{L}), 0.1 \mu \mathrm{L}$ RNase inhibitor (40 U/ $\mu \mathrm{L}), 0.5 \mu \mathrm{L} 25 \mathrm{mM} \mathrm{MgCl}_{2}$, and the reaction was adjusted to $25 \mu \mathrm{L}$ with nuclease free water. One-step RT-PCR reaction was performed in automated thermal cycler (GeneAmp PCR System 9700; Applied Biosystem, US) with $60 \mathrm{~min}$ at $42^{\circ} \mathrm{C}$ and $3 \mathrm{~min}$ at $94{ }^{\circ} \mathrm{C}$ for RT reaction in 1 cycle, followed by 35 cycles of DNA amplification with $30 \mathrm{sec} 94{ }^{\circ} \mathrm{C}, 1 \mathrm{~min}$ at $50{ }^{\circ} \mathrm{C}$ and $1 \mathrm{~min}$ at $72{ }^{\circ} \mathrm{C}$. The amplicons was electrophoresed on $1 \%$ agarose gel in $0.5 \times$ TBE (Tris-Boric acid-EDTA) buffer, stained using EtBr, and visualized under UV transilluminator.

CMV Detection by RT-PCR. Total RNA was used as template for one-step RT-PCR as in CMV detection above, using primers pair $1 \mathrm{~F}$ (5'-AGCTAACCATGGAC
AAATCTGGATGTCCCAAT-3') and 1R (5'-AGCAT TCCATGGGGCAGTTTGAAGCAATACTACC-3') (Namba et al., 1991). The reactions were $60 \mathrm{~min}$ at $42{ }^{\circ} \mathrm{C}$ and $3 \mathrm{~min}$ at $93.5^{\circ} \mathrm{C}$ for $\mathrm{RT}$ reaction in 1 cycle, followed by 35 cycles of DNA amplification with 45 $\sec 93.5{ }^{\circ} \mathrm{C}, 45 \mathrm{sec}$ at $55{ }^{\circ} \mathrm{C}, 1 \mathrm{~min}$ at $72{ }^{\circ} \mathrm{C}$. The amplicons was electrophoresed on $1 \%$ agarose gel in $0.5 \times$ TBE (Tris-Boric acid-EDTA) buffer, stained using $\mathrm{EtBr}$, and visualized under UV transilluminator.

Extraction of Total DNA. Basically, total DNA extraction was the same as the total RNA extraction explained above. The difference was after pelleting the debris by the addition of $500 \mu \mathrm{L}$ of chloroform/ isoamyl alcohol $(24: 1, \mathrm{v} / \mathrm{v})$, the preparation was centrifuged at $14,000 \mathrm{rpm}$ for $15 \mathrm{~min}$. DNA was then precipitated by the addition of $3 \mathrm{M}$ ammonium acetate and isopropanol, then incubated overnight at $-20{ }^{\circ} \mathrm{C}$, followed by centrifugation at $12,000 \mathrm{rpm}$ for $10 \mathrm{~min}$. DNA pellet was dissolved in $50 \mu \mathrm{L}$ of TE buffer $1 \mathrm{x}(10 \mathrm{mM}$ Tris$\mathrm{HCl} \mathrm{pH} 8.0,1 \mathrm{mM}$ EDTA) and was ready for amplification.

Geminivirus Detection by PCR. Geminivirus detection was performed by DNA amplification using specific primers pair for Begomovirus, SPG1 (5'-CCC CKGTGCGWRAATCCAT-3') and SPG2 (5'-ATCCVA AYWTYCAGGGAGCT AA-3') (Li et al., 2004). PCR reaction was conducted in $25 \mu \mathrm{L}$ premix Go Taq Green (Promega, Japan) using Automated Thermal Cycler (GeneAmp PCR System 9700; Applied Biosystem, US). The reactions were 35 cycles $\left(1 \mathrm{~min}\right.$ at $94{ }^{\circ} \mathrm{C}$ of denaturation, $1 \mathrm{~min}$ at $50^{\circ} \mathrm{C}$ of annealing, and $7 \mathrm{~min}$ at $72{ }^{\circ} \mathrm{C}$ of extension). The amplicons was electrophoresed on $1 \%$ agarose gel in $0.5 \times$ TBE (Tris-Boric acid-EDTA) buffer, stained using EtBr, and visualized under UV transilluminator.

Nucleotide Sequence Analysis. The nucleotide sequence analysis was carried out in The DNA Sequencing BioSM Laboratories (Malaysia). The DNA sequence results were analyzed using the Basic Local Aligment Search Tool (BLASTN) program on the National Center for Biotechnology Information website (www.ncbi.nlm.nih.gov) to compare the sequences of targeted virus to the close related viral nucleotide sequences deposited in GenBank Data base. Nucleotide homology and Identity Matrix Sequences were analyzed using Clustal W multiple alignment program and Bioedit 7.05 software (Hall, 1999), respectively. 


\section{RESULTS AND DISCUSSION}

Samples of yardlong bean leaves were collected from endemic areas of viral diseases in yardlong bean centers in Sukoharjo District, Central Java Province, Indonesia. The samples of yardlong bean leaves were then grouped into 12 groups based on their symptoms on two grouping criteria i.e. leaf discoloration and leaf malformation relative to healthy leaves (Figure 1-5).

The 12 sample groups were obtained as follows: 4 sample groups were Geminivirus single-infected (Figure 1), 4 sample groups were Potyvirus singleinfected (Figure 2), One sample group was CMV singleinfected (Figure 3), one sample group was GeminivirusPotyvirus double-infected (Figure 4), and one sample group was Potyvirus-CMV double-infected (Figure 5). Nurulita et al. (2015) reported that from 15 samples of yardlong bean leaves collected from 6 districts in Central Java, West Java, and Special Region of Yogyakarta, 7 samples were single infected with Geminivirus, 2 samples were single infected with Potyvirus, no sample was infected with CMV, 4 samples were double infected with Geminivirus and Potyvirus, and 2 samples were not infected with any of the virus.

Yardlong bean leaves which were single infected with Geminivirus, showed a variety of symptoms ranging from discoloration (changes in color) to malformation (changes in shape). However, in general it can be described that the symptoms of yardlong bean leaves infected with Geminivirus were striking yellow color (yellow mosaic), curved (cupping), and dwarf (Figure 1). The Geminivirus infection is shown by the presence of a $912 \mathrm{bp}$ band of nucleic acid as a result of amplification using a primers pair specific to Geminivirus
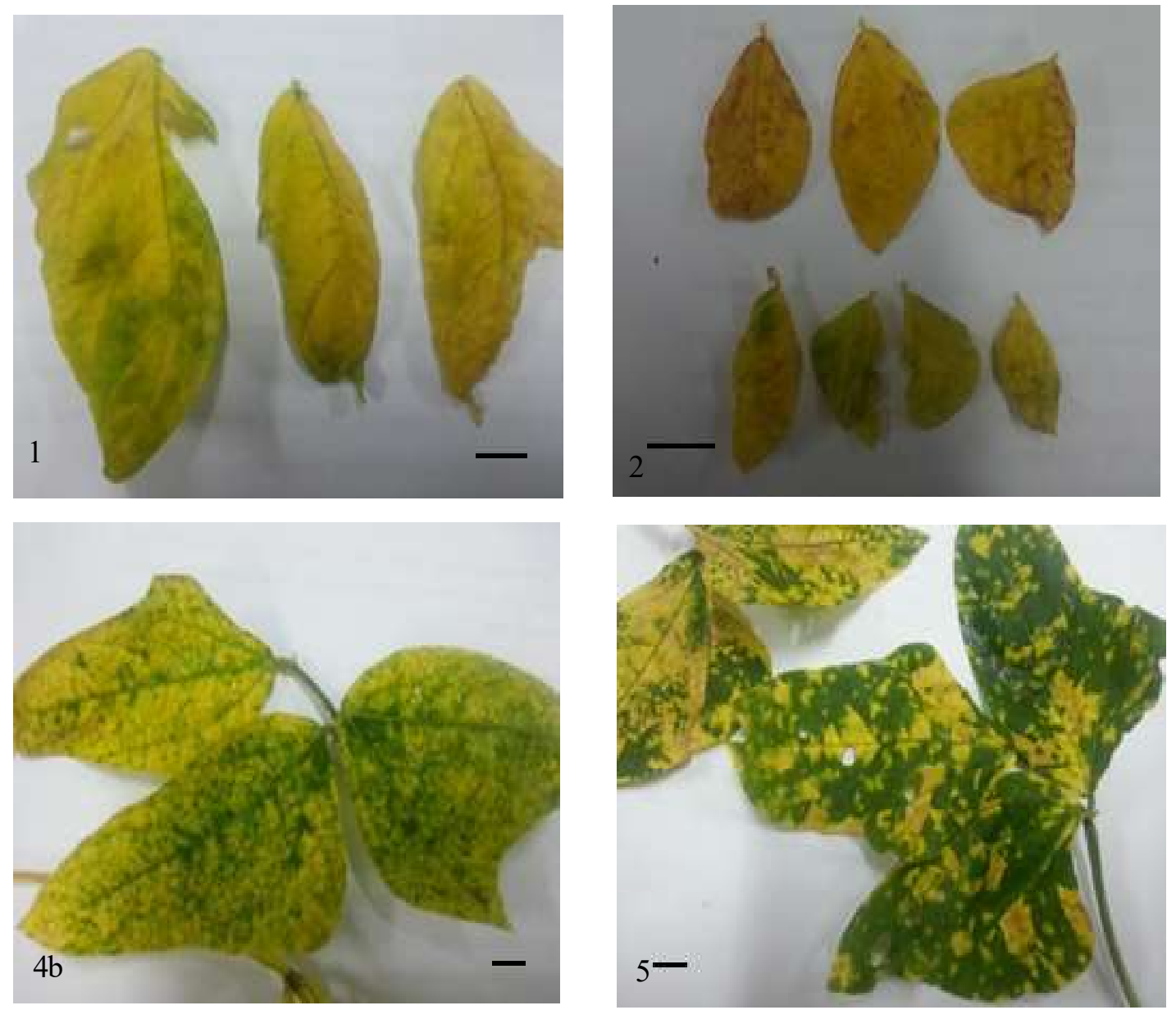

Figure 1. Symptoms variation of yardlong bean leaves infected with Geminivirus (leaves are striking yellow in color/yellow mosaic, curving/cupping, and dwarfing. (1) Leaves have striking yellow color with a little mosaic, cupping, leaves size are smaller; (2) Leaves have striking yellow color almost orange, cupping, leaves size are smaller; (4b) Leaves have striking yellow mosaic following the pattern of leaf veins, leaf veins are green, dominant in yellow; (5) Leaves have striking yellow mosaic following the pattern of leaf veins, leaf veins are green. The number refers to the sample group. Bar $=1 \mathrm{~cm}$. 
(Figure 6). Nurulita et al. (2015) reported that a single infection of Geminivirus in yardlong bean showed a variety of symptoms of leaves yellowing and yellow mosaic.
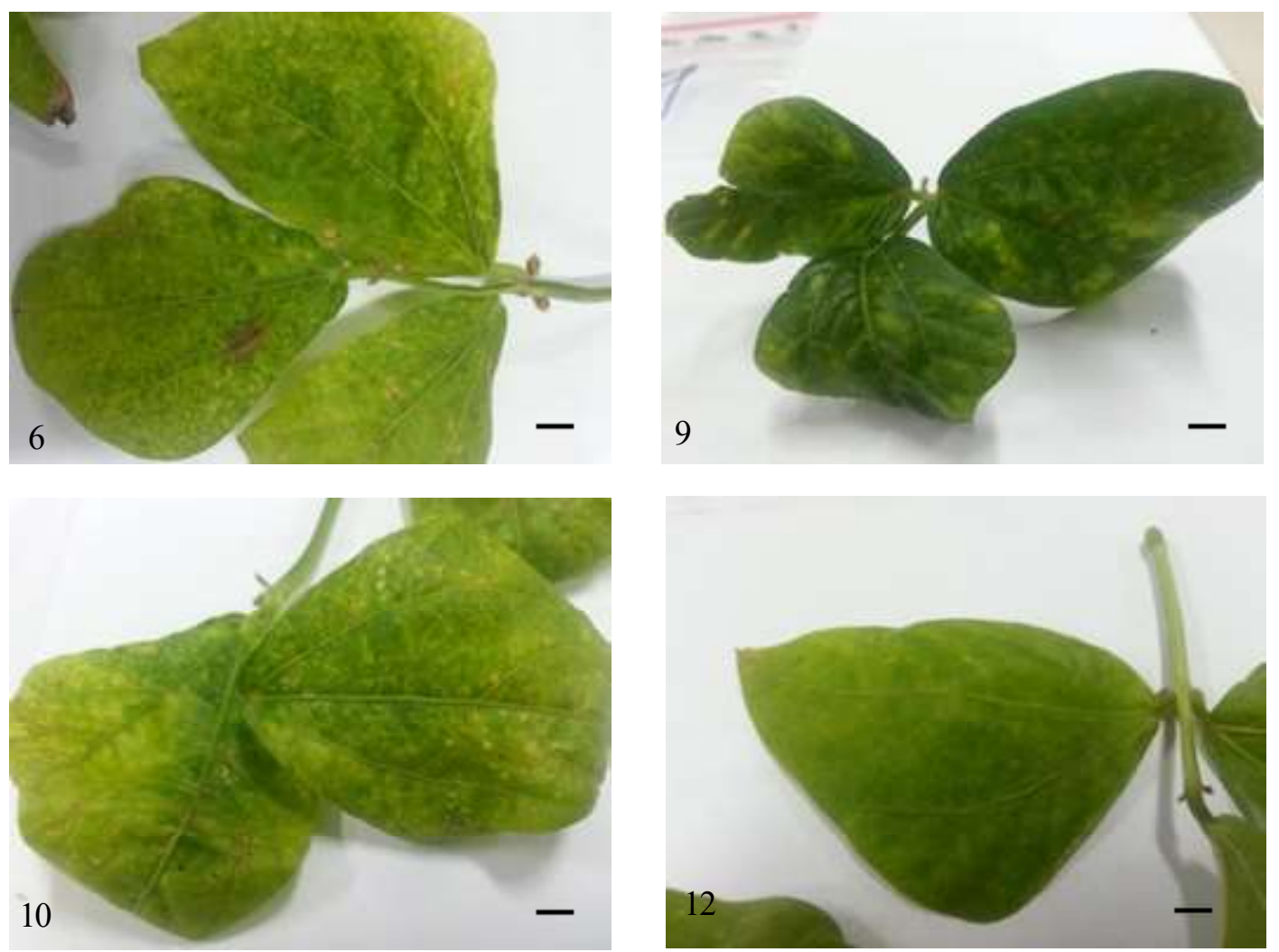

Figure 2. Symptoms variation of yardlong bean leaves infected with Potyvirus (leaves are light green mosaic/ chlorosis, cupping/curling, and dwarfing. (6) Leaves have light green mosaic following the pattern of leaf veins, leaf veins are thick and hard; (9) Leaves have dark green color with a light yellow mosaic on the tip/edge of the leaf, leaf curl/roll; (10) Leaves have light green mosaic following the pattern of leaf veins, leaf veins are thick and hard and have yellow mosaic; (12) Leaves have light green color with yellow mosaic on the leaf veins. The number refers to the sample group. Bar $=1 \mathrm{~cm}$.

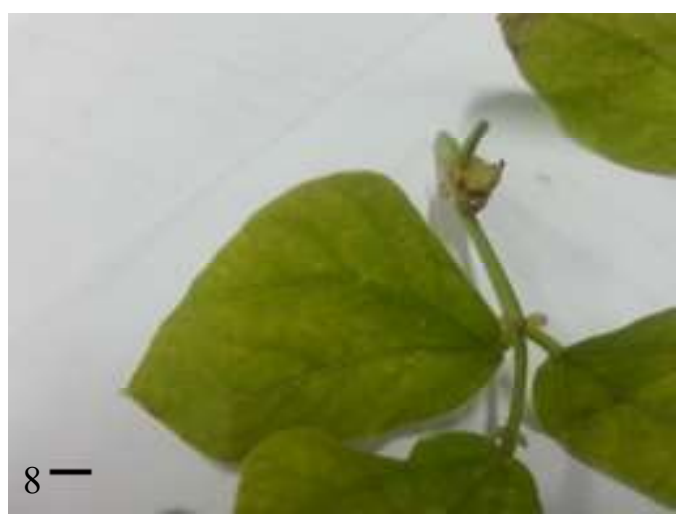

Figure 3. Symptoms of yardlong bean leaves infected with CMV(leaves were mosaic, chlorosis, without/minimal changes in leaf shape). (8) Leaves have light green color with light yellow mosaic. Leaf veins are thick and hard. The number refers to the sample group. Bar $=1 \mathrm{~cm}$. 


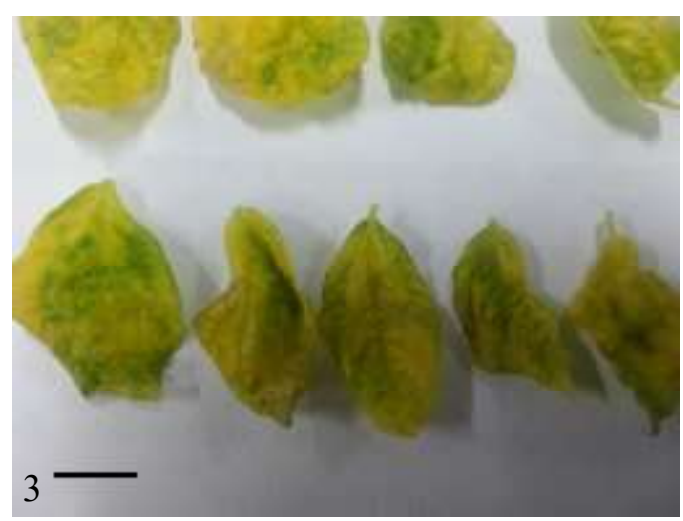

Figure 4. Symptoms variation of yardlong bean leaves double infected with Geminivirus and Potyvirus (leaves are dominant striking yellow color/yellow mosaic, cupping/curling, and dwarfing). (3) Leaves have striking light yellow color with light green mosaic around the leaf veins, cupping, leaves are small. The number refers to the sample group. $B a r=1 \mathrm{~cm}$.

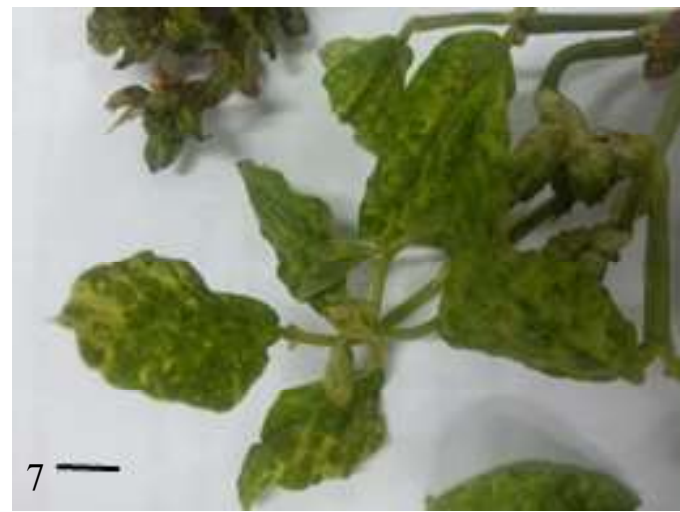

Figure 5. Symptoms of yardlong bean leaves double infected with Potyvirus and CMV (leaves are mosaic chlorosis, curling/dwarfing). (7) Leaves have green color with light yellow mosaic, curling, leaves are small. The number refers to the sample group. Bar $=1 \mathrm{~cm}$.

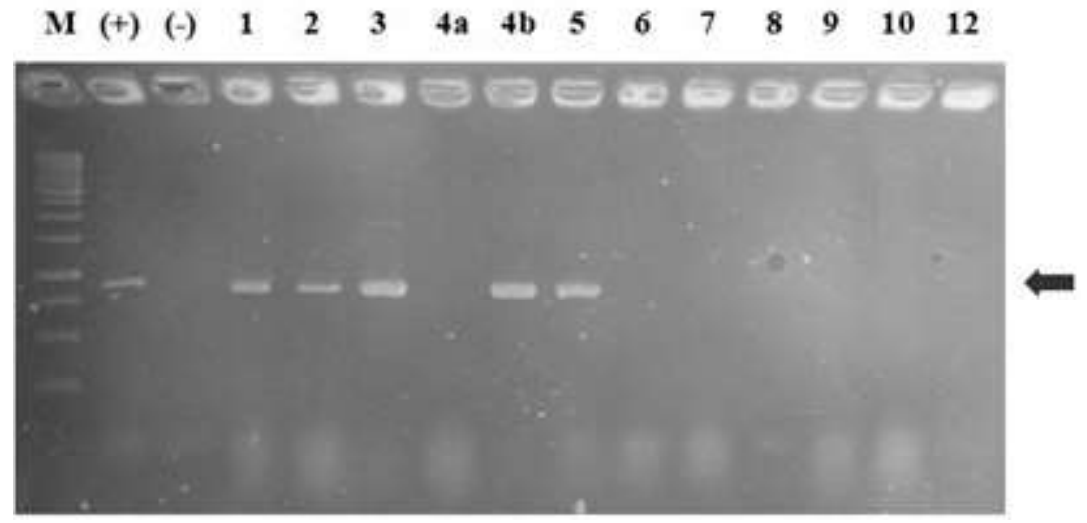

Figure 6. The results of the molecular detection of Geminivirus. Marker used in this study was $1 \mathrm{~kb}$ Plus DNA ladder (Invitrogen); (+) Positive standard using Geminivirus isolate of Laboratory of Virology, Bogor Agricultural University; (-) negative standard using virus-free yardlong bean leaves. The arrow indicates the bands of $912 \mathrm{bp}$. The lane numbers at the top refer to the sample group explained in the Results and Discussion and also in Figure 1-5. 
leaves infected with Potyvirus were light green mosaic (chlorosis), (cupping/curling), and dwarfing (Figure 2). The Potyvirus infection is shown by the presence of a $328 \mathrm{bp}$ band of nucleic acid as a result of amplification using a primers pair specific to Potyvirus (Figure 7). Nurulita et al. (2015) reported that a single infection of Potyvirus in yardlong bean showed symptoms of mosaic vein banding.

Yardlong bean leaves which were single infected with CMV, showed symptoms of light green leaf with a light yellow mosaic, veins were thick and hard. More specifically it can be described that the symptoms of yardlong bean leaves infected with CMV were mosaic, chlorosis, without/minimal changes in leaf shape (Figure 3). The CMV infection is proven by the presence of a $320 \mathrm{bp}$ band of nucleic acid as a result of amplification using a primers pair specific to CMV (Figure 8).

Yardlong bean leaves which were double-infected with Geminivirus-Potyvirus, showed the combined symptoms of each infecting virus plus symptoms that were a result of synergistic effect of the two viruses infection (Figure 1, 2, and 4). In more detail, it can be described that the symptoms of yardlong bean leaves double infected with Geminivirus-Potyvirus were dominant striking yellow leaves (yellow mosaic), cupping/curling, and dwarfing. Nurulita et al. (2015)

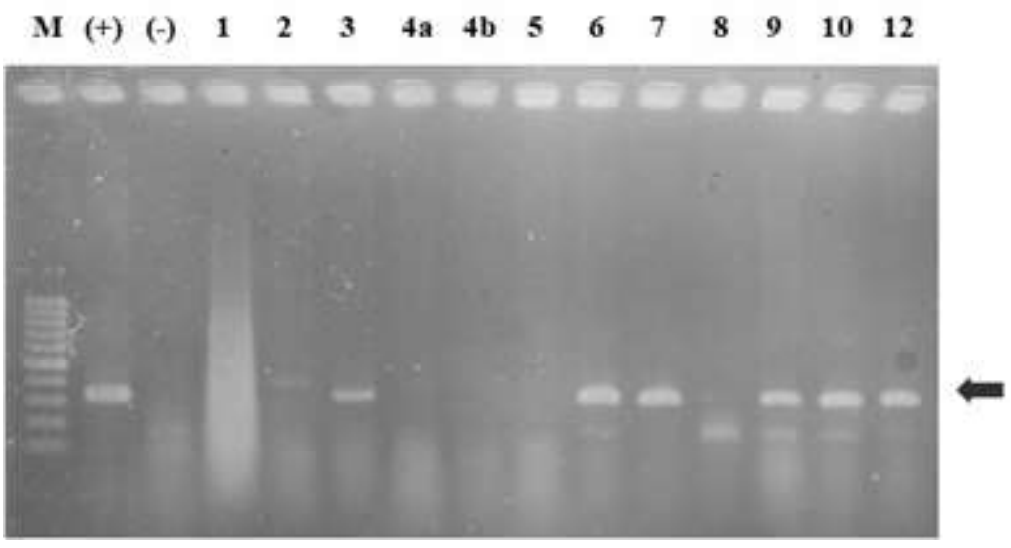

Figure 7. The results of the molecular detection of Potyvirus. Marker used in this study was $1 \mathrm{~kb}$ Plus DNA ladder (Invitrogen); (+) Positive standard using Potyvirus isolate of Laboratory of Virology, Bogor Agricultural University; (-) Negative standard using virus-free yardlong bean leaves. The arrow indicates the bands of $328 \mathrm{bp}$. The lane numbers at the top refer to the sample group explained in the Results and Discussion and also in Figure 1-5.

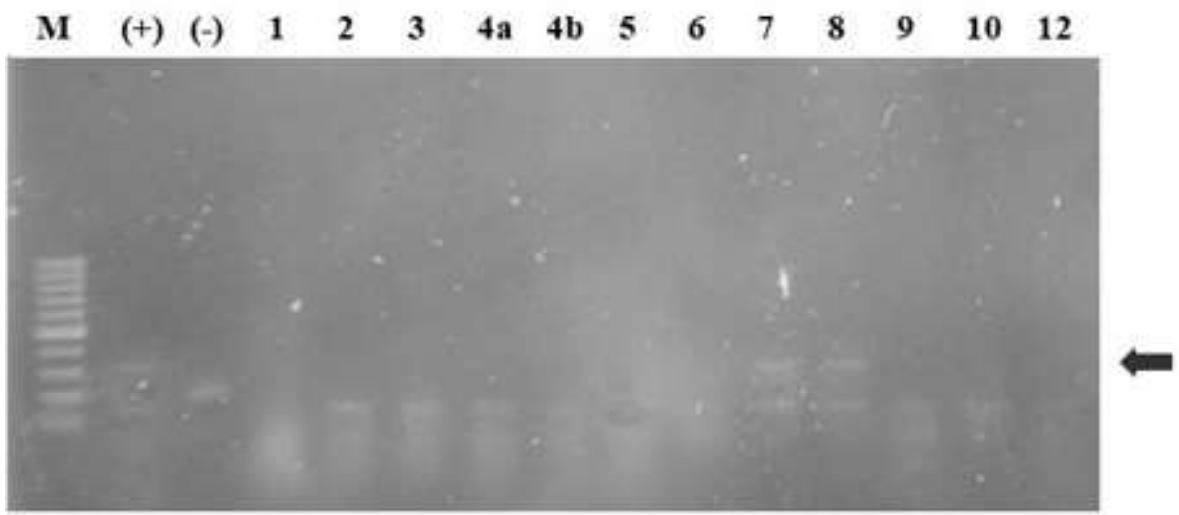

Figure 8. The results of the molecular detection of CMV. M, $1 \mathrm{~kb}$ Plus DNA ladder, Invitrogen; (+) Positive standard using CMV isolate of Laboratory of Virology, Bogor Agricultural University; (-) Negative standard using virus-free yardlong bean leaves. The arrow indicates the bands of $320 \mathrm{bp}$. The lane numbers at the top refer to the sample group explained in the Results and Discussion and also in Figure $1-5$. 
reported that double infection of Geminivirus and Potyvirus in yardlong bean showed symptom variation of yellow mosaic and yellow.

Yardlong bean leaves which were double-infected with Potyvirus-CMV also showed the combined symptoms of each infecting virus plus symptoms that were a result of synergistic effect of the two viruses infection (Figure 2, 3, and 5). It can be described that the Potyvirus-CMV double infection of yardlong bean leaves showed mosaic chlorosis and curling/dwarfing. In Indonesia, double infection of Potyvirus and CMV in yardlong bean was first reported by Damayanti et al. (2009) in the Bogor area. The symptoms were heavy yellow mosaic on leaves, deformation and mosaic in pods. Damayanti et al. (2010) also reported the presence of double infection of Potyvirus and CMV with symptoms of severe mosaic to strong yellow mosaic, and vein clearing.

Then four leaves samples were chosen to analyze the viral nucleic acid. The four samples were sample number $4 \mathrm{~b}$ (single infected Geminivirus), sample number 6 (single infected Potyvirus), sample number 3 (double infected Geminivirus-Potyvirus), and sample number 7 (double infected Potyvirus-CMV).

The results of BLASTN analysis through NCBI of DNA sequences from samples number $4 \mathrm{~b}$ and 3 showed that the infecting virus was Geminivirus, and had a high homology to several Geminivirus isolates from Indonesia which were deposited in the GeneBank database. The Geminivirus nucleotide sequences from samples number $4 \mathrm{~b}$ and 3 have the highest percentage of nucleotide similarity to isolate of Indonesian Mungbean yellow mosaic India virus (MYMIV) from Brebes which are $98 \%$ and $99 \%$, respectively (Table 1). The existence of MYMIV in Indonesia was first reported by Nurulita et al. (2015). The authors collected yardlong bean diseased leaves samples from various locations in Java including Tegal, Klaten, Magelang, Subang and Bogor which were all positively infected with MYMIV. Based on the results of nucleic acid analysis, it was revealed that the virus was a group with MYMIV from Bangladesh, India, Pakistan and Nepal.

The results of BLASTN analysis through NCBI of DNA sequences from samples number 6 and 7 showed that the infecting virus was Potyvirus, and had a high homology with several Potyvirus isolates from abroads which were deposited in the GeneBank database. The Potyvirus nucleotide sequences from samples number 6 and 7 have the highest percentage of nucleotide similarity to isolate of Bean common mosaic virus (BCMV) from Cina of $92 \%$ and $90 \%$, respectively (Tabel 1). Melinda et al. (2015) have reported the presence of BCMV associated with yardlong bean yellow mosaic disease in West and Central Java. From the samples collected from the two regions, it was revealed that 4 isolates (Cangkurawok, Subang, Solo and Sleman) had the highest homology and had a close relationship to BCMV-B1C from Taiwan. Whereas 2 isolates (Cirebon and Tegal) had the highest homology to BCMV-NL1 from the UK, and had close relationships

Table 1. The results of BLASTN analysis of nucleotide sequence of viruses detected in yardlong bean leaves and their homology values to the viral isolates from GeneBank Data base

\begin{tabular}{|c|c|c|c|c|c|}
\hline $\begin{array}{l}\text { Sample } \\
\text { group } \\
\text { number }\end{array}$ & Primer pairs & $\begin{array}{l}\text { Nucleotide } \\
\text { size (bp) }\end{array}$ & Closely related with & $\begin{array}{l}\text { Homology } \\
(\%)\end{array}$ & $\begin{array}{l}\text { Accession } \\
\text { number }\end{array}$ \\
\hline 3 & $\begin{array}{l}\text { Universal primers for } \\
\text { Geminivirus (SPG1 \& } \\
\text { SPG2). Amplicons size } \\
912 \text { bp }\end{array}$ & 909 & $\begin{array}{l}\text { Mungbean yellow mosaic } \\
\text { India virus Indonesia } \\
\text { (Brebes isolate) }\end{array}$ & 99 & JN368436.1 \\
\hline $4 \mathrm{~b}$ & $\begin{array}{l}\text { Universal primers for } \\
\text { Geminivirus (SPG1 \& } \\
\text { SPG2). Amplicons size } \\
912 \text { bp }\end{array}$ & 908 & $\begin{array}{l}\text { Mungbean yellow mosaic } \\
\text { India virus Indonesia } \\
\text { (Brebes isolate) }\end{array}$ & 98 & JN368436.1 \\
\hline 6 & $\begin{array}{l}\text { Universal primers for } \\
\text { Potyvirus (MJ1 \& MJ2). } \\
\text { Amplicons size } 328 \text { bp }\end{array}$ & 333 & $\begin{array}{l}\text { Bean common mosaic virus } \\
\text { (China) }\end{array}$ & 92 & KC832502.1 \\
\hline 7 & $\begin{array}{l}\text { Universal primers for } \\
\text { Potyvirus (MJ1 \& MJ2). } \\
\text { Amplicons size } 328 \text { bp }\end{array}$ & 334 & $\begin{array}{l}\text { Bean common mosaic virus } \\
\text { (China) }\end{array}$ & 90 & KJ807819.1 \\
\hline
\end{tabular}


to the BCMV-NL1 from the UK and BCMV-BlC Y from China.

Based on the results of the analysis, it could be said that Geminivirus and Potyvirus isolates infecting yardlong bean in the Soloraya areas are closely related to the Geminivirus and Potyvirus isolates that have been reported by the previous researchers (Nurulita et al., 2015; Melinda et al., 2015). Both viruses are transmitted by whitefly and a group of aphids which were found abundantly on the Island of Java. Whitefly, Bemisia tabaci (Homoptera: Aleyrodidae) has been reported exist in Indonesia in 1938 (Kalshoven, 1981). The group of aphids also has long been reported exist in Indonesia (Kalshoven, 1981).

In the field, MYMIV transmission occurs through the help of insects vector (whitefly) and via mechanically, although rarely (Fauquet et al., 2005). BCMV in the field also could be transmitted by insect vectors. But the vector for this virus is Aphid in non-persistent manner. Other than that, BCMV also could be transmitted by seeds (Fauquet et al., 2005). Similar with BCMV, CMV in the field could be transmitted through the help of Aphids in a non-persistent manner (Fauquet et al., 2005).

Based on the way of transmission in the field, the three viruses are transmitted in more or less the same way, i.e. through insect vectors, through seeds, and also by mechanical means. This gives an implication to the control strategy of the viruses. Thus, the strategy to control the three viruses can be formulated that is control of insect vectors, the use of virus-free seeds, and careful handling of plants.

\section{CONCLUSION}

There are three kinds of viruses were detected infecting yardlong bean in Solo Raya. The three viruses were Mungbean yellow mosaic geminivirus (MYMIV), Bean common mosaic Potyvirus (BCMV), and Cucumber mosaic virus (CMV). These viruses could infect yardlong bean both individually or doubly. Infection of two kinds of virus in a yardlong bean showed symptoms of each virus plus a synergistic effect where the symptoms become more severe. Geminivirus and Potyvirus infecting yardlong bean in the Soloraya are closely related (have a high nucleotides similarity) to Geminivirus and Potyvirus isolates that have been reported by the Indonesian previous researchers.

The implication of the findings obtained from this study on disease management strategies is that both MYMIV, BCMV, and CMV have the same mode of transmission through seeds, insects vector, and mechanics. Therefore, the control can be done in the same strategy that is using healthy seeds, pest control (especially piercing-sucking insect) and handling plants carefully.

\section{ACKNOWLEDGMENT}

This research was supported by Bacth.2 Dana Anggaran Penerimaan Negara Bukan Pajak (PNBP)Universitas Sebelas Maret, Tahun Anggaran 2017. Nomor : 1073/UN27. 21/PP/2017. The authors are grateful to Miss Susanti Mugi Lestari for technical assistance.

\section{REFERENCES}

Damayanti TA, Alabi OJ, Naidu RA, \& Rauf A. 2009. Severe outbreak of a yellow mosaic disease on the yard long bean in Bogor, West Java. HAYATI J. Biosci. 16(2): 78-82.

Damayanti TA, Alabi OJ, Rauf A, \& Naidu RA. 2010. The Occurrence of Bean common mosaic virus and Cucumber mosaic virus in yardlong beans in Indonesia. Plant Dis. 94(4): 478.

Duriat AS. 1998. Kacang Panjang: Komoditas Andalan Gizi. Kerjasama Balai Penelitian Sayuran-Pusat Penelitian dan Pengembangan Hortikultura serta Badan Penelitian dan Pengembangan Pertanian, Jakarta.

Doyle JJ \& Doyle JL. 1987. A rapid DNA isolation of procedure for small quantities of fresh leaf tissue. Phytochem. Bull. 19(1): 11-19.

Fauquet CM, Mayo MA, Maniloff J, Desselberger U, \& Ball LA. 2005. Virus Taxonomy: Eighth Report of the International Committee for the Taxonomy of Viruses. Academic Press, San Diego.

Hall TA. 1999. BioEdit: A user-friendly biological sequence alignment editor and analysis program for Window 95/98/NT. Nucl. Acids Symp. Series. 41: 95-98.

Kalshoven LGE. 1981. The Pests of Crops in Indonesia. Revised and Tranlated by P.A. Van der Laan. PT Ichtiar Baru-Van Hoeve, Jakarta.

Li R, Salih S, \& Hurtt S. 2004. Detection of geminiviruses in sweetpotato by polymerase chain reaction. Plant Dis. 88(12): 1347-1351. 
Marie-Jeanne V, Ioos R, Peyre J, Alliot B, \& Signoret P. 2000. Differentiation of Poaceae potyviruses by reverse transcription-polymerase chain reaction and restriction analysis. J. Phytopathol. 148(3): 141-151.

Melinda, Damayanti TA, \& Hidayat SH. 2015. Identifikasi molekuler Bean common mosaic virus yang berasosiasi dengan penyakit mosaik kuning kacang panjang. J. HPT Tropika. 15(2): 132-140.

Namba S, Ling K, Gonsalves C, Gonsalves D, \& Slightom JL. 1991. Expression of the gene encoding the coat protein of Cucumber mosaic virus (CMV) strain WL appears to provide protection to tobacco plants against infection by several different CMV strains. Gene. 107(2): 181-188.

Nurulita S, Hidayat SH, Mutaqin KH, \& Thomas JE. 2015. Molecular characterization of Begomovirus infecting yard long bean (Vigna unguiculata subsp. sesquipedalis L.) in Java, Indonesia. Biotropia. 22(1): 53-60.

Semangun H. 2004. Penyakit-Penyakit Tanaman Hortikultura di Indonesia. Gadjah Mada University Press, Yogyakarta.

Sastro Y. 2016. Budidaya Sayuran di Pekarangan Sempit. Balai Pengkajian Teknologi Pertanian Jakarta. Badan penelitian dan Pengembangan Pertanian. Kementerian Pertanian, Jakarta.

Taufik Y. 2015. Statistik Produksi Hortikultura Tahun 2014. Direktorat Jenderal Hortikultura, Kementerian Pertanian, Jakarta.

Tsai WS, Shih SL, RaufA, Safitri R, Hidayati N, Huyen BTT, \& Kenyon L. 2013. Genetic diversity of Legume yellow mosaic begomoviruses in Indonesia and Vietnam. Ann. Appl. Biol. 163(3): 367-377.

Triharso, Somowiyarjo S, Sulandari S, \& Hartono S. 1998. Plant viruses in Indonesia. In: Murayama D, Agrawal HO, Inoue T, Kimura I, Shikata E, Tomaru K, Tsuchizaki T, \& Triharso (Eds.). Plant Viruses in Asia. pp. 287-346. Gadjah Mada University Press, Yogyakarta. 